\title{
Production of transgenic Alstroemeria plants containing virus resistance genes via particle bombardment
}

\author{
Jong Bo Kim
}

Received: 20 April 2020 / Revised: 27 April 2020 / Accepted: 27 April 2020

(C) Korean Society for Plant Biotechnology

\begin{abstract}
Transgenic Alstroemeria plants resistant to Alstroemeria mosaic virus (AlMV) were generated through RNAmediated resistance. To this end, the friable embryogenic callus (FEC) of Alstroemeria was induced from the leaf axil tissue and transformed with a DNA fragment containing the coat protein gene and 3'-nontranslated region of AlMV through an improved particle bombardment system. The bar gene was used as a selection marker. More than 300 independent transgenic FEC lines were obtained. Among these, 155 lines resistant to phosphinothricin (PPT) were selected under low stringent conditions. After increasing the stringency of PPT selection, 44 transgenic lines remained, and 710 somatic embryos from these lines germinated and developed into shoots. These transgenic shoots were then transferred to the greenhouse and challenged with AlMV. In total, 25 of the 44 lines showed some degree of resistance. PCR analysis confirmed the presence of the viral sequence. Virus resistance was observed at various levels. Establishment of an efficient transformation system for Alstroemeria will allow inserting transgenes into this plant to confer resistance to viral and fungal pathogens. Accordingly, this is the first report on the production of a transgenic virus-resistant Alstroemeria and lays the foundation for alternative management of viral diseases in this plant.
\end{abstract}

Keywords Alstroemeria, Alstroemeria Mosaic Virus, Friable embryogenic callus, Particle bombardment, Virus resistance

J. B. Kim $(\bowtie)$

Department of Biotechnology, Research Institute for Biomedical and Health Sciences, College of Biomedical \& Health Sciences, Glocal Campus. Konkuk University, Choong-Ju, 27478, Korea e-mail: jbhee1011@kku.ac.kr

\section{Introduction}

Alstroemeria is a popular ornamental plant grown for the cut-flower industry or as indoor potted plants. It is primarily propagated vegetatively, and thus viral infections are a serious concern. Viruses cause considerable loss in both yield and quality in many crops (Gielen 1995). As a rule, strategies for the control of viral diseases involve the control of vector groups through the use of insecticides, meristem culture, and phytosanitary cultural practices, as well as through the introduction of resistant cultivars. Unfortunately, each of these measurements has limitations (Dasgupta et al. 2003).

Although several studies have attempted to produce virus-free Alstroemeria plants by using a meristem culture (Chiari and Bridgen 2002), viruses continue to be a major problem in Alstroemeria species since meristem-derived Alstroemeria plants can be re-infected during harvest or transport. Numerous viruses are currently considered critical for Alstroemeria. Examples include Alstroemeria carla virus (AlCV), Alstroemeria mosaic virus (AlMV), cucumber mosaic virus (CMV), tomato spotted wilt virus (TSWV), Alstroemeria streak virus (AlSV), and Impatiens necrotic spot virus (INSV) (Van Zaayen 1995). Of these viruses, AlMV is considered the most endemic. Moreover, it is difficult to detect or prevent AlMV contaminations in Alstroemeria cultures.

AlMV is a species of the potyvirus genus in the family Potyviridae, one of the largest and most widely distributed families of plant viruses. The potyvirus genus is known for its ability to cause severe damage in various crops (Hollings and Brunt 1981). The viral symptoms vary depending on the virus strain, infected Alstroemeria variety, and environmental factors present. A typical symptom of AlMV is the leaf streaking with elongated light green or darkened spots, which develop along the veins and flower breaks (Chiari and Bridgen 2002). 
As in other crops, no effective physical or chemical treatment has been reported for the viral diseases in Alstroemeria. This is mostly due to three critical drawbacks in the development of virus-resistant Alstroemeria plants. The first drawback is the difficulty in detecting viral symptoms, resulting in many breeders or farmers to have infected mother stocks. The second drawback is the re-infection of previously virus-free Alstroemeria plants produced by meristem culture. Re-infection may occur, during propagation through rhizome splitting or during harvest, transport, or vector activity. The third drawback is the limited number of resistant genotypes in the germplasm collection, restricting the number of potential crosses for the generation of elite varieties. Due to these complications, a virus-resistant Alstroemeria cultivar has not been developed yet.

Potential resistance to plant viruses can be provided by either expressing part of the viral genome or virally associated sequences. This acquired resistance is now known as pathogenderived resistance (PDR) (Satyavathi et al. 2005). PDR can be divided into two groups: coat protein-mediated resistance (CPMR), in which the production of a coat protein results in resistance, and RNA-mediated resistance in which the accumulation of the viral sequences leads to resistance (Satyavathi et al. 2005). Although CPMR can confer resistance onto a wide range of viruses, the acquired resistance is rather weak, whereas RNA-mediated resistance can confer substantially higher resistance, albeit to a narrower range of viruses (Beachy 1997). Recently, genome-editing technology using CRISPR/Cas9 was used to show resistance to BCTV (Beet curly top virus) in $N$. benthamiana plants (Ali et al. 2016; Baltes et al. 2015). Up to now, there is few report to edit RNA virus via CRISPR/Cas 9 system because Guide RNA-Cas 9 can recognize and cut for only DNA viruses (Kim et al. 2018).

Despite the numerous strategies for developing transgenic plants resistant to viruses, there has been only one clear commercial success, which enhanced the resistance of papaya to papaya ringspot virus by stably expressing one of the viral genes (Campbell et al. 2004).

To introduce the PDR concept into an Alstroemeria breeding program, an efficient and reliable genetic transformation system is required. In addition to the virusresistance trait, genetic transformation systems may provide opportunities to improve other agriculturally important traits, such as resistance to bacterial or fungal diseases or abiotic stresses, in breeding stocks or directly in elite genotypes. Due to these advantages, genetic transformation is regarded as a promising technique in agricultural breeding programs. It can also be used for simultaneous introduction of mul- tiple genes (Campbell et al. 2004), highlighting the potential of this technique in monocot breeding programs for vegetatively propagated ornamentals, such as Alstroemeria, crocus, gladiolus, lily, narcissus and tulip.

The objective of this study was to produce AlMVresistant transgenic Alstroemeria plants by using particle bombardment.

\section{Materials and Methods}

\section{Plant material}

Friable embryogenic callus (FEC) induced from Alstroemeria leaves with axil tissues (VV024, tetraploid cultivar from Van Staaveren B.V, The Netherlands) was used in the experiments as described by Kim et al (2006). FECs were cultured with plate count agar (PCA) medium (Sofiari et al. 1998) in the dark at $18^{\circ} \mathrm{C}$, with the medium refreshed every 4 weeks. The $\mathrm{pH}$ of the PCA medium was adjusted to 6.0 prior to autoclaving at $121^{\circ} \mathrm{C}$ and $120 \mathrm{kPa}$ for 15 min unless stated otherwise. FECs were selected for particle bombardment at 6 months of age unless otherwise stated.

Plasmids for virus resistance experiments

Total RNA was isolated from an Alstroemeria plant infected with AlMV and used for first-strand cDNA synthesis by using general oligo-dT primer P5902 (Van der Vlugt et al. 1999). The cDNA was then PCR-amplified with primers AlMV-UP02 (upstream) and P9502 (downstream) (Table 1). The PCR product was run on an agarose gel. The 1,300-bp amplicon was isolated from the gel and cloned into a pGEM-T vector. Resulting plasmid pAlMV-PV was used to amplify the viral coat protein (CP) gene and $3^{\prime}$ non-translated region ( $3^{\prime}$-NTR) of AlMV. A short adaptor sequence was included at the $5^{\prime}$ end of each primer to facilitate the cloning of the amplicon into plant transformation vector pAHC25. For AlMV CP-UP2, this sequence consisted of a SacI recognition site (GAGCTC) downstream

Table 1 PCR primer sequences used in cloning of the AlMV $\mathrm{CP}$ and 3'-NTR. The parts in italics in the AlMV specific primers are linker sequences and are not virus specific

\begin{tabular}{ll}
\hline Primer & \multicolumn{1}{c}{ Sequence } \\
\hline AlMVCP-UP02 & 5'-TTAGAGCTCGAGTTGGACGATGATTTTGA-3' \\
AlMV-TotDW & 5'-GGGTGAGTCACCGTAACGATAGAAT-3' \\
P9502 & 5'-GGATCCTTTTTTTTTTTTTTTTT-3' \\
\hline
\end{tabular}




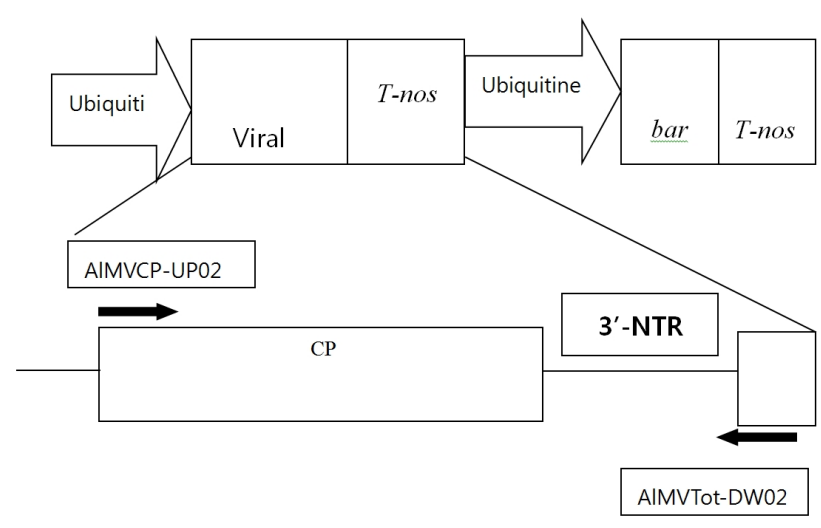

Fig. 1 Transgene expression cassette (pXYZ000: Viral construct) (Arrows indicate the positions of the two primers on plasmid pAlMV-PV)

of three nucleotides (TTA). For AlMV Tot-DW, the adaptor consisted of a GGG triplet to generate a Smal recognition site upon the directional ligation of the PCR fragments derived from the SacI/Smal digestion of pAHC25. Using this primer pair, the 1258-bp fragment containing both the $\mathrm{CP}$ and $3^{\prime}$-NTR of AlMV was amplified from pAIMV-PV, resolved by agarose gel electrophoresis, isolated from the gel using the High Pure PCR Product Purification Kit (Boehringer), digested with SacI, and re-purified with the same kit. RFLP analysis by using the restriction enzymes DdeI, NsiI, and BstOI confirmed the integrity of the amplicon. Vector pAHC25 was digested with Smal/SacI to remove the GUS gene and ligated with the amplicon, thereby resulting in plasmid pXYZ000 (Fig. 1). E. coli JM109 was transformed with this plasmid, and the recombinants were assessed by colony PCR for the presence of the desired insert, followed by gel electrophoresis. Plasmid pXYZ000 was used for transforming the plants.

DNA coating and particle bombardment

The Promega Wizard Midiprep DNA purification kit was used to isolate plasmid DNA. The final DNA concentration was set to $1.1 \mathrm{mg} / \mathrm{ml}$ in sterilized distilled water. Plasmid DNA $(25 \mu \mathrm{g})$ was then mixed with $15 \mathrm{mg}$ gold particles (size $1.6 \mathrm{~mm}$ ) in an Eppendorf tube by vortexing for $1 \mathrm{~min}$ and centrifuged at $11,000 \mathrm{rpm}$ for $10 \mathrm{~s}$. The following ingredients were then individually added: $30 \mathrm{ml} 5 \mathrm{M} \mathrm{NaCl}$, $5 \mathrm{ml} 2 \mathrm{M}$ Tris- $\mathrm{HCl}$ ( $\mathrm{pH} \mathrm{8.0),} 100 \mathrm{ml} \mathrm{0.1} \mathrm{M} \mathrm{spermidine,}$ $100 \mathrm{ml} \mathrm{25 \%} \mathrm{PEG1550,} 100 \mathrm{ml} 2.5 \mathrm{M} \mathrm{CaCl}_{2}$, and $965 \mathrm{ml}$ sterile double-distilled water. After re-centrifugation, the coated gold particles in the pellet were washed with $1 \mathrm{ml}$ sterilized water, centrifuged again, and resuspended with $10 \mathrm{ml} \mathrm{100 \%}$ ethanol. Finally, $163 \mathrm{ml}$ of this suspension of
DNA-coated gold particles was pipetted onto a macrocarrier (BioRad, California, U.S.A) and used for bombardment.

For bombardment experiments, approximately $200 \mathrm{mg}$ of FEC clumps grown on PCA medium was evenly spread in a circle with a $2.5 \mathrm{~cm}$ diameter at the center of a Petri dish $(60 \times 15 \mathrm{~mm})$ containing PCA medium. Then, these FEC clumps were bombarded according to the protocol used by Kim JB (2020). After the FEC clumps were bombarded, they were transferred to a selection medium (SM) consisting of Murashige and Skoog (1962) basal salts with vitamins, $0.5 \mathrm{mg} / \mathrm{l} \mathrm{BA}, 30 \mathrm{~g} / 1$ sucrose, $2.75 \mathrm{~g} / 1$ Gelrite (pH 6.0). This SM contained $20 \mathrm{mg} / 1$ PPT (phosphinothricin) as a selectable agent.

Generation of transgenic Alstroemeria plants resistant to AlMV

Ten days before particle bombardment, approximately 200 $\mathrm{mg}$ of fast-growing yellow FEC on PCA medium $(9 \mathrm{~cm}$ Petri dish) were broken into small pieces ( $c a .2-5 \mathrm{~mm}$ ) and placed in a circle with a diameter of $2.5 \mathrm{~cm}$ on a Petri dish. Two days after bombardment, FEC cultures were transferred to regeneration medium (RM). Ten days later, cultures were transferred to RM containing $20 \mathrm{mg} / \mathrm{l} \mathrm{PPT}$. Yellow, fast-growing FECs were dissected into small pieces for stringent selection with PPT. The selected FEC cultures were grown at $18^{\circ} \mathrm{C}$ under a $16 \mathrm{~h} / 8 \mathrm{~h}$ (light/dark) photoperiod for $2 \sim 4$ months and transferred to fresh RM at regular monthly intervals. Transgenic shoots were produced from the FEC culture and transferred to the same selective RM medium. Shoot clusters developed into plantlets $6 \sim 8$ months after the transformation. Finally, putative transgenic plants were planted into the soil in the greenhouse and maintained at $15 \sim 23^{\circ} \mathrm{C}$ (day/night).

Molecular characterization of regenerated transgenic lines

PCR analysis was conducted to demonstrate the presence of the viral sequences in the transformed plants. Genomic plant DNA was extracted from $250 \mathrm{mg}$ of the regenerated putative transgenic lines, as described by Lin et al (2000). These DNA samples ( $2 \mathrm{mg}$ each) were analyzed by PCR. To detect viral sequence $\mathrm{CP}+3^{\prime}$-NTR $(1,258 \mathrm{bp})$, the forward primer was 5'-TTAGAGCTCGAGTTGGACGATGATTTTGA-3', and the reverse primer was $5^{\prime}$-GGGTGAGTCACCGTAAC GATAGAAT-3' (Table 1). Reactions were carried out using 30 pmol of each primer, $300 \mathrm{mM}$ dNTP, $0.25 \mathrm{u}$ Taq polymerase in $50 \mathrm{mM} \mathrm{KCl}, 1.5 \mathrm{mM} \mathrm{MgCl}_{2}$, and $10 \mathrm{mM}$ Tris- $\mathrm{HCl}$, $\mathrm{pH}$ 7.3. The PCR program was $94^{\circ} \mathrm{C}$ initial melting for 5 
min, followed by 35 cycles of $94^{\circ} \mathrm{C}$ for $30 \mathrm{~s}, 51^{\circ} \mathrm{C}$ for $30 \mathrm{~s}$, and $72^{\circ} \mathrm{C}$ for $30 \mathrm{~s}$. The final extension step was $7 \mathrm{~min}$ at $72^{\circ} \mathrm{C}$.

Optimization of the AlMV inoculation conditions

The optimum AlMV inoculum concentration and frequency were investigated to obtain the maximum infection rate with minimal damage to Alstroemeria plants. Before inoculation, the plants were dusted with 400-mesh carborundum powder. Five leaves of 1-week-old Nicotiana benthamiana systemically infected with AlMV were ground in $10 \mathrm{ml}$

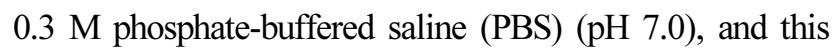
inoculum was marked as $1 \times$. When $5 \mathrm{ml}$ of the buffer was used, the inoculum was marked as $2 \times$. Inoculated leaves were re-inoculated three additional times with the intervals of $4 \sim 5$ days.

Virus inoculation of transgenic Alstroemeria plants in the greenhouse

After the preliminary experiment, $N$. benthamiana (positive control; 5 plants), non-transformed Alstroemeria (negative control, 5 plants), and transgenic Alstroemeria plants were mechanically inoculated using carborundum powders (400 mesh) and the sap of AlMV-infected Nicotiana benthamiana leaves in $5 \mathrm{ml}$ PBS ( $2 \times$ concentration). Five to ten minutes after the inoculation, the infected Alstroemeria plants were thoroughly washed with tap water to prevent the carborundum powder from drying.

For the first inoculation of transgenic plants, the inoculum was used at $2 \times$ concentration per 10 young Alstroemeria plants (at the $8 \sim 10$ full leaf stage). The second inoculation was carried out 5 days after the first inoculation (day zero, 0 dpi: days post-infection). All the 44 putative transgenic lines were inoculated twice. The third inoculation was performed for 17 transformed lines out of the 44 transgenic lines 5 days after the second inoculation, to assess whether an additional inoculation had any effect on the level of resistance in the putative transgenic Alstroemeria plants. To detect the presence and expression of the AlMV transgene in the inoculated Alstroemeria plants, polyclonal antibodies against the AlMV were used. Double Antibody SandwichEnzyme-Linked Immunosorbent Assay was carried out following a modified protocol (Clark and Adams 1977). Absorbance at $405 \mathrm{~nm}$ was measured using a microplate autoreader ELISA EL-808 (Bio-TEK Instruments, Winooski, USA) 30 minutes later. All the inoculated plants were checked for the presence of the virus by DAS-ELISA 2,
4, and 6 weeks after the inoculation. Samples were recorded as ELISA-positive when their absorbance value was at least twice of the mean absorbance value of healthy control plants, as described by Lines et al (2002).

\section{Statistical analysis}

The data are presented as mean \pm standard error (SE) and analyzed using the least significant difference (LSD) test $(p=0.05)$ for multiple comparisons (SPSS for Windows version 10.0 ' statistical software).

\section{Results}

Production of virus-resistant plants through particle bombardment

The optimized bombardment protocol previously described in this chapter was used to produce plants containing virus-resistance genes. From sixteen independent transformation experiments with pXYZ000, 357 independent transgenic callus lines were obtained. These lines proliferated well on the selection medium (SM) with various concentrations of PPT for $6 \sim 8$ months following the bombardment. After these subcultures, resistant pieces of FEC were separated from the necrotic tissue. The first PPT-resistant FEC cultures (155 lines) were observed $2 \sim 3$ weeks after the bombardment.

Putative transgenic somatic embryos were generated on SM from the bombarded FEC cultures $5 \sim 6$ weeks after the transformation. After further growth, they were allowed to germinate for an additional 4 weeks on the regeneration medium. When PCR analysis was conducted to calculate the proportion of the transgenic lines in all the sub-cultured PPT-positive transgenic FEC lines on SM, $\geq 70 \%$ of the lines on SM tested positive (data not shown). Stringent PPT-based selection of the transgenic lines was completed 8 months after the bombardment.

Following this stringent selection procedure, 44 putative transgenic lines were generated and then transferred to PPT-free regeneration medium. From these 44 lines, a total of 849 germinated embryos (GE) with a couple of shoots were obtained after $4 \sim 5$ months of culture on PPT-free regeneration medium. For further growth and development, 710 healthy GE with $\geq 2$ shoots were transferred to the rooting medium to initiate root formation. After $4 \sim 5$ weeks of culture on the rooting medium, plants displayed healthy roots. The plants were transferred to the greenhouse 
$9 \sim 10$ months after the transformation. Here, they were acclimatized and allowed to grow until the $8 \sim 10$ leaf stage and then challenged with AlMV.

Only 35\% (248 out of 710 from the 44 independent transgenic lines) of the transgenic Alstroemeria plants survived after transferring to the greenhouse. The remaining $65 \%$ (462 out of 710) transgenic plants died due to fungal contamination (41\%: 189 out of 462) or lack of root formation (59\%: 273 out of 462). Three to four months after the transfer, approximately $7 \%$ of the transgenic plants in the greenhouse flowered.

Preliminary test for the virus inoculation procedure

Alstroemeria plants were infected after the top $3 \sim 4$ young leaves had been mechanically inoculated three or four times with the AlMV inoculum. In the preliminary experiments, there was no significant difference in the levels of virus infection among different time points of virus challenge (data not shown). However, two rounds of inoculation with $2 \times$ inoculum concentration resulted in sufficient infection with the least damage on the plants (Table 2). This protocol was used in all the experiments with the transformed Alstroemeria plants. Nearly $90 \%$ of the control plants $(9 / 10)$ were ELISA-positive at $14 \mathrm{dpi}$ and $100 \%$ at $28 \mathrm{dpi}$. The ELISApositive plants exhibited the typical symptoms of AlMV infection, such as yellowing at the tip of the leaves and subsequent necrosis with light greenish-yellow (or white) streaks or sections.
Characterization of the virus resistance in the transgenic Alstroemeria plants

Virus inoculation was performed with randomly selected 150 transgenic Alstroemeria plants derived from the 44 independent transgenic lines in the greenhouse. Non-transformed Alstroemeria plants infected with the virus were used as a positive control (PC) and non-transformed plants without any contact with the virus were used as a negative control (NC). Moreover, N. benthamiana was also used as a positive control. The AlMV-infected control Alstroemeria plants and $N$. benthamiana tested highly positive with ELISA ( $>$ 2.0), while the negative control plants showed a very low value. Transgenic or non-transgenic plants that showed twice ELISA $\mathrm{OD}_{405 \mathrm{~nm}}$ value than the non-infected control plant were considered susceptible. The ELISA $\mathrm{OD}_{405 \mathrm{~nm}}$ values of the inoculated transgenic Alstroemeria plants ranged from 0.08 to 1.28 , whereas those of the positive Alstroemeria control plants and N. benthamiana were 2.0 and 3.23 , respectively. The transgenic lines were recorded as described in materials and methods section, according to their $\mathrm{OD}_{450 \mathrm{~nm}}$ values $[>0.230$, susceptible (ELISA-positive); < 0.230, resistant (ELISA-negative)].

Most of the infected plants showed no visible symptoms until $14 \mathrm{dpi}$, and 30 out of the 44 lines were regarded as resistant based on the ELISA $\mathrm{OD}_{405 \mathrm{~nm}}$ readings. The most resistant 10 lines and the most susceptible 10 lines were subsequently selected and maintained for another 4 weeks without additional inoculation. At $56 \mathrm{dpi}$, these lines were again evaluated for the presence of AlMV by ELISA. Consequently, only 5 lines (line $8,10,11,19$, and 20) were

Table 2 Optimization of inoculation procedure with AlMV for Alstroemeria VV024

\begin{tabular}{cccc}
\hline $\begin{array}{c}\text { Concentration } \\
\text { of inoculum }\end{array}$ & $\begin{array}{c}\text { Frequency of } \\
\text { inoculation }^{\mathrm{b}}\end{array}$ & $\begin{array}{c}\text { Damage to } \\
\text { plants }^{\mathrm{c}}\end{array}$ & $\begin{array}{c}\text { ELISAreadings } \\
(\text { O.D }\end{array}$ \\
\hline Non-inoculation & 0 & - & $0.04 \pm 0.01$ \\
1X & 2 & - & $0.24 \pm 0.07$ \\
$1 \mathrm{X}$ & 3 & +++ & $0.51 \pm 0.22$ \\
$1 \mathrm{X}$ & 4 & - & $0.97 \pm 0.39$ \\
$2 \mathrm{X}$ & 2 & - & $0.88 \pm 0.17$ \\
$2 \mathrm{X}$ & 3 & ++ & $1.28 \pm 0.15$ \\
$2 \mathrm{X}$ & 4 & ++ & $1.31 \pm 0.28$ \\
\hline
\end{tabular}

${ }^{a}$ When the virus inoculum is prepared with an infected $N$. benthamiana leaf with a size of $5 \mathrm{~cm}$ and $10 \mathrm{ml}$ buffer, it is called $1 \times$. If the inoculum prepared $5 \mathrm{ml}$ buffer with the same infected leaf, it would be called $2 \times$.

${ }^{b}$ The second inoculation was performed 4-5 days after the first inoculation. The third inoculation was conducted 5 days after the second inoculation. The fourth inoculation was done as the interval of third inoculation.

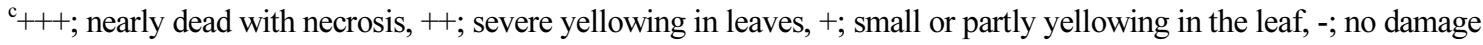

${ }^{\mathrm{d}}$ O.D data presented as the mean of six replicates, and measured 2 weeks after the final inoculation. 


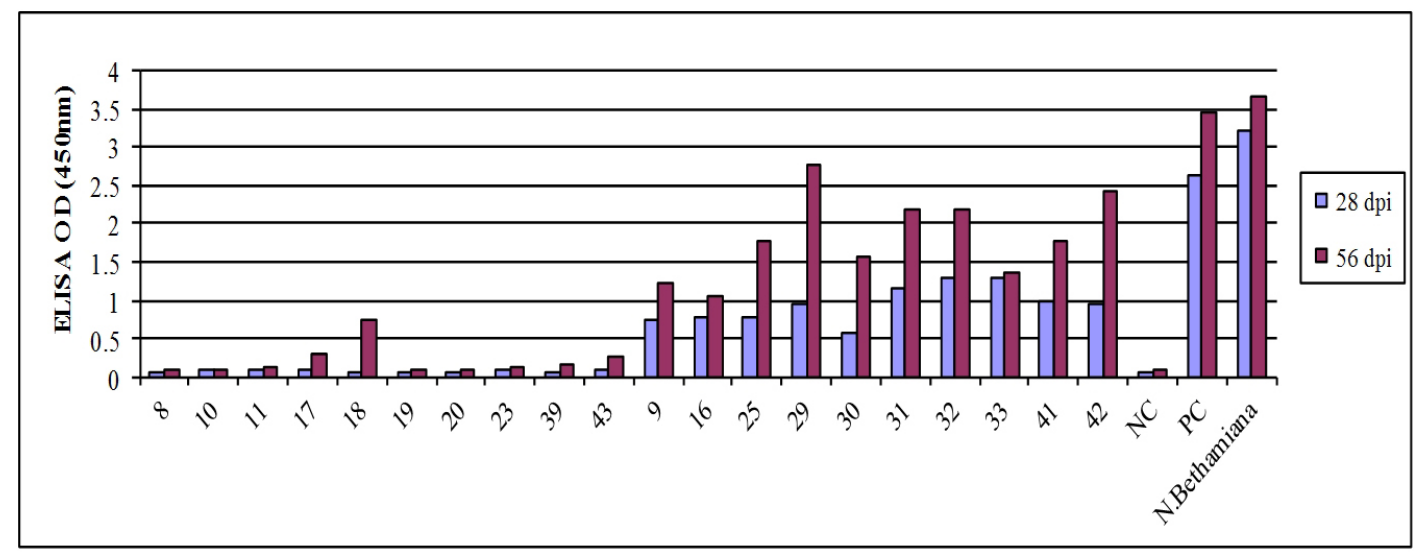

Fig. 2 Evaluation of AlMV accumulation in transgenic Alstroemeria lines at 28 and 56 days post inoculation. The data indicate the average of ELISA $\left(\mathrm{OD}^{405 \mathrm{~nm}}\right)$ values determined for the mean of 3 plants for transgenic lines (NC: Negative control, PC: Positive control, resistant lines (line 8, 10, 11, 17, 18, 19, 20, 23 39, 43), susceptible lines (line 9, 16, 25, 29, 30, 31, 32, 33, 41, 42))

A

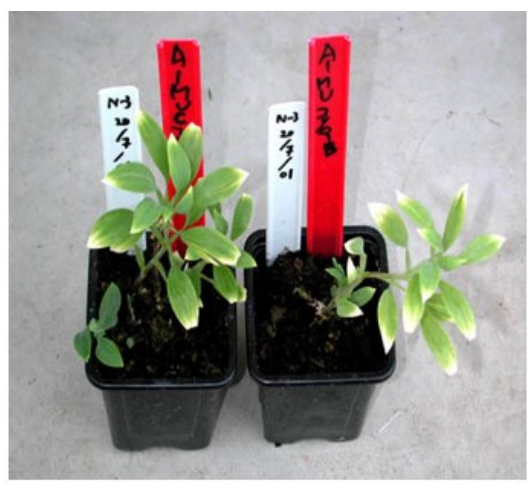

B

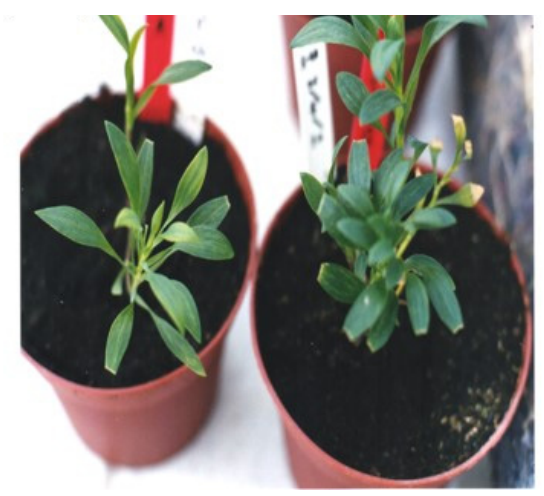

C

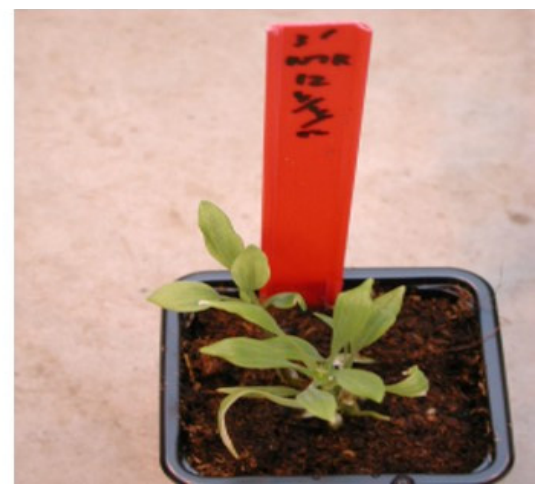

Fig. 3 Corresponding photographs to the level of morphology evaluation 6 weeks after inoculation (A: inoculated control, B: non-inoculated control, $\mathrm{C}$ : moderate growing transgenic lines)

still resistant 8 weeks after the inoculation, whereas the rest of the 10 most resistant lines were found to have been infected with AlMV by then (Fig. 2).

Regarding the symptoms, there was also no positive correlation between the level of virus-resistance and symptom expression. Seven susceptible lines showed the symptoms (Fig. 3A). The other three susceptible lines showed intermediate growth rates between figure $3 \mathrm{~B}$ and $3 \mathrm{C}$ (data not shown). However, the negative control plants showed vigorous growth (Fig. 3B) and the positive control plants showed weak growth (Fig. 3C). Infected $N$. benthamiana showed yellowing and partial necrosis in the leaves (data not shown). By $10 \sim 12$ weeks after the inoculation, approximately $60 \%$ of the inoculated transgenic Alstroemeria plants had died for unknown reasons, although they grew well in the first $4 \sim 6$ weeks after the inoculation. The transgenic line had a moderate growth rate and normal morphology even when challenged with the virus. The rest $40 \%$ of the transgenic Alstroemeria plants survived $>20$ weeks after

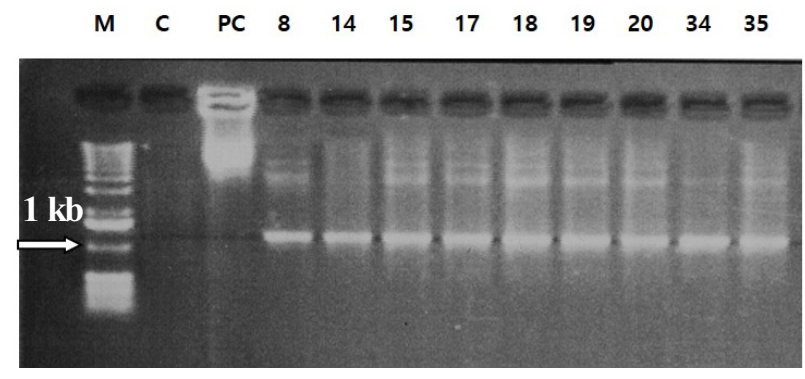

Fig. 4 PCR analysis of the transgenes (viral sequence $(\mathrm{CP}+3$ 'NTR): $1,258 \mathrm{bp}$ ) in the transformed Alstroemeria plants (black arrows indicate the corresponding band, and white arrow indicate the size of marker). M: Marker, C: Control (non-transformed Alstroemeria plant), PC: Positive control (pAHC25)

Lines $-8,14,15,17,18,19,20,34,35$ (all transgenic lines from resistance group)

the inoculation. PCR analysis was performed to determine the presence of the viral sequence (Fig. 4). The transgenic plants that yielded DNA products of the expected sizes were considered positive. 


\section{Discussion}

Although conventional breeding has highly contributed to ornamental breeding, there is still a demand for genetic transformation techniques to alter individual traits in many ornamental crops, especially for traits for virus-resistance. Since advances in biotechnology can solve these problems, the production of genetically-modified plants with improved resistance against to disease is now a promising approach (Sasaya et al. 2014).

In this study, FEC cultures induced from the leaf axil tissues of Alstroemeria plants were transformed with AlMV-derived viral sequences through particle bombardment. Virus-resistant transgenic plants have been obtained against several potyviruses, such as Tobacco etch virus (Dougherty et al. 1994) and PVY (Van der Vlugt et al. 1992), by transferring an untranslatable RNA from the corresponding virus to the plant. In addition, the use of this kind of untranslatable coat protein construct allows efficient detection of the virus by using ELISA because no background transgene expression is present (Lines et al. 2002). The expression of the viral fragment has been evaluated using PCR and ELISA.

Of the 44 independent transgenic lines obtained in this study, a large number of them were $\mathrm{PCR}^{+} / \mathrm{PPT}^{+}$, but some were also ELISA-positive. Among the transgenic Alstroemeria plants, considerable differences in their reactions to virus infection could be observed. However, it is hard to determine if the variations in the transformed lines, including resistance level and morphology patterns, were associated with the AlMV infection. It might be due to either sample variation or other physiological parameters among the independent transgenic lines. Overall, the resistance level assessed by ELISA was not correlated with developmental or morphological characteristics.

The results represented in Figure 2 indicate that a considerable number of RNA-mediated transgenic Alstroemeria plants had a short-term tolerance but not long-term.

There have been a number of strategies to obtain virus resistance in crops. Generally, two mechanisms are widely known to exhibit resistance to virus infection (Lomonossoff 1995). Coat-protein-mediated or RNA-mediated resistance has been used for the development of virus-resistant transgenic plants. In this study, however, only RNA-mediated resistance was used because coat-protein-mediated resistance often shows difficulty in distinguishing the resistance and expression levels of potyviruses. RNA-mediated resistance that normally does not need protein expression often shows virus resistance at very high levels or even leads to near immunity (Wang et al. 2001).
Thus, using the RNA-mediated strategy, transgenic Alstroemeria plants resistant to AlMV were generated by particle bombardment. This is the first report to show that RNAmediated resistance is potentially applicable to obtain resistant Alstroemeria. Resistance seems to originate from the presence of CP RNA sequence rather than on the accumulation of viral CP (Masmoudi et al. 2002).

Tolerance to AlMV infection in some of our transgenic Alstroemeria plants has been obtained in this study, but a more efficient transformation system should be pursued to obtain a higher degree of virus resistance. There was also severe inhibition of rooting and overall growth, which might be caused by the presence of PPT in the selection medium. Therefore, other selection methods, such as nonchemical approaches, should be tested to minimize the risk of somaclonal variation as well as inhibition of growth and plant development.

In summary, our results suggest that transgenic Alstroemeria plants resistant to AlMV can be produced through RNA-mediated resistance.

\section{Acknowledgement}

The author wish to thank Van Staaveren B.V. (The Netherlands) for kindly providing VV024 Alstroemeria plants. We also thank Bert Essenstam (Unifarm) and Dirkjan Huigen (Plant Breeding, Wageningen University) for taking care of the plants. This research was supported by grants from the Ministry of Education, Republic of Korea, and the Laboratory of Plant Breeding, Wageningen University.

\section{References}

Ali Z, Ali S, Tashkandi M, Zaidi SS and Mahfouz MM (2016) CRISPR/Cas9-mediated immunity to geminiviruses: differential interference and evasion. Sci Rep 6:26912

Baltes NJ, Hummel AW, Konecna E, Cegan R, Bruns AN, Bisaro DM (2015) Conferring resistance to geminivirus with the CRISPR/Cas prokaryotic immune system. Nat Plants 1:15145

Beachy RN (1997) Mechanisms and applications of pathogen-derived resistance in transgenic plants. Curr Opin Biotechnol 8:215-220

Campbell MA, Fitzgerald HA, Ronald PC (2004) Handbook of Plant Biotechnology. John Wiley \& Sons Ltd. pp. 395-411

Chiari A, Bridgen MP (2002) Meristem culture and virus elimination in Alstroemeria. Plant Cell, Tiss Organ Cult 68:49-55

Clark MF and Adams AN (1977) Characteristics of the microplate method of enzyme-linked immunosorbent assay for the detection of plant viruses. J of Gen Virol 34:475-483

Dasgupta I, Malathi VG, Mukherjee SK (2003) Genetic engineering 
for virus resistance. Curr Sci 84:341-354

Dougherty WG, Lindbo JA, Smith HA, Parks TD, Swaney S and Proebsting WM (1994) RNA-mediated virus resistance in transgenic plants: exploitation of a cellular Pathway possibly involved in RNA degradation. Mol Plant-Microbe Interact 7: 544-552

Gielen JJL (1995) Molecular breeding for virus resistance, an applied approach in vegetable crops. Ph.D. thesis, Wageningen University, Wageningen, The Netherlands

Hollings ML, Brunt AA (1981) In: Kurstak E (ed.), Handbook of Plant Virus Infections: Comparative Diagnosis. Elsevier, The Netherlands, pp 731-807

Kim JB, Raemakers CJJM, Jacobsen E, Visser RGF (2006) Efficient somatic embryogenesis in Alstroemeria. Plant Cell Tiss Organ Cult 86:233-238

Kim JB (2020) An efficient protocol for the production of transgenic Alstroemeria plants via particle bombardment. J of Plant Biotechnol 47:66-72

Kim NY, Hong JS and Jeong RD (2018) Plant immunity against viruses: Moving from lab to the field. Res Plant Dis 24(1): 9-25

Lin HS, Van der Toorn C, Raemakers CJJM, Visser RGF, De Jeu MJ and Jacobsen E(2000) Genetic transformation of Alstroemeria using particle bombardment. Mol Breed 6:369-377

Lines RE, Persley D, Dale JL, Drew R, and Bateson MF (2002) Genetically engineered immunity to Papaya ringspot virus in Australian papaya cultivars. Mol Breed 10:119-129

Lomonossoff GP (1995) Pathogen-derived resistance to plant virus. Ann Rev Phytopathol 33:323-343

Masmoudi K, Yacoubi I, Hassairi A, Elarbi LN, Ellouz R (2002) Tobacco plants transformed with an untranslatable form of the coat protein gene of the Potato virus $Y$ are resistant to viral infection. Eur J of Plant Patho 108:285-292
Murashige T and Skoog F (1962) A revised medium for rapid growth and bioassays with tobacco tissue cultures. Physiol Planta 15:473-497

Sasaya T, Nakazono-Nagaoka E, Saika H, Aoki H, Hiraguri A, Netsu O, Uehara-Ichiki T, Onuki M, Toki S, Saito K and Yatou O (2014) Transgenic strategies to confer resistance against viruses in rice plants. Front Microbiol 4:409

Satyavathi SVV, Prasad V, Kirthi N, Maiya SP, Savithri HS, Lakshmi Sita G (2005) Development of cotton transgenics with antisense $A V 2$ gene for resistance against cotton leaf curl virus (CLCuD) via Agrobacterium tumefaciens. Plant Cell Tiss Organ Cult 81:55-63

Sofiari E, Raemakers CJJM, Bergervoet JEM, Jacobsen E, Visser RGF (1998) Plant regeneration from protoplasts isolated from friable embryogenic callus of cassava. Plant Cell Rep 18: 159-165

Van der Vlugt RAA, Ruiter RK and Goldbach R (1992) Evidence for sense RNA-mediated protection to PVY-N in tobacco plants transformed with the viral coat protein cistron. Plant Mol Biol 20:631-639

Van der Vlugt RAA, Steffens P, Cuperus C, Barg E, Lesemann DE, Bos L, and Vetten HJ (1999) Further evidence that Shallow yellow stripe virus (SYSV) is a distinct potyvirus and re-identification of Welsh onion yellow stripe virus as a SYSV strain. Phytopathology 89:148-155

Van Zaayen (1995) Alstroemeria. In: Loebenstein G, Lawson RH and Brunt AA (eds) Virus and Virus-like Diseases of Bulb and Flower Crops (pp 237-249), John Wiley \& Sons, Chichester, UK

Wang X, Eggenberger AL, Nutter Jr. FW, Hill JH (2001) Pathogen-derived transgenic resistance to soybean mosaic virus in soybean. Mol Breed 8:119-127 